\title{
Climate change impacts on potential maize yields in Gambella Region, Ethiopia
}

\author{
Azeb W. Degife ${ }^{1}$ (D) Florian Zabel $^{1} \cdot$ Wolfram Mauser $^{1}$
}

Received: 15 November 2019 / Accepted: 31 March 2021 / Published online: 25 May 2021

(C) The Author(s) 2021

\begin{abstract}
Changing climate conditions are supposed to have particularly strong impacts on agricultural production in the tropics with strong implications on food security. Ethiopia's economy is profoundly dominated by agriculture, contributing to around $40 \%$ of the gross domestic product. Thereby, Ethiopia is one of the most vulnerable countries to the impact of climate change and has a wide gap in regional climate change impact studies. In this study, we systematically investigate climate change impacts on yields for the Gambella region in Ethiopia, exemplarily for maize. Here, we show how yields change until 2100 for RCPs 2.6, 4.5, and 8.5 from a climate model ensemble under rainfed and irrigated conditions. While rainfed yields decrease by $15 \%$ and $14 \%$ respectively for RCPs 2.6 and 4.5, yields decrease by up to $32 \%$ under RCP 8.5. Except for RCP 8.5, yields are not further decreasing after 2040-2069. We found that temperature increase, changing soil water availability, and atmospheric $\mathrm{CO}_{2}$ concentration have different effects on the simulated yield potential. Our results demonstrate the dominance of heat response under future climate conditions in the tropical Gambella region, contributing to $85 \%$ of total yield changes. Accordingly, irrigation will lose effectiveness for increasing yield when temperature becomes the limiting factor. $\mathrm{CO}_{2}$, on the other hand, contributes positively to yield changes by $8.9 \%$ for RCP 8.5 . For all scenarios, the growing period is shorted due to increasing temperature by up to 29 days for RCP 8.5. Our results suggest that new varieties with higher growing degree days are primarily required to the region for adapting to future climate conditions.
\end{abstract}

Keywords Climate change $\cdot$ Agriculture $\cdot$ Regional study $\cdot$ Crop model

\section{Introduction}

Many studies agree that climate change is real and that the poorest and most vulnerable people will be the most affected by reduced availability, lower quality, and higher prices of food (Barbier and Hochard 2018; Diffenbaugh and Burke 2019; Hallegatte et al. 2018). The last three decades were each warmer than every previous decade since temperature records

Communicated by Diana Sietz

Azeb W. Degife

a.degife@iggf.geo.uni-muenchen.de

Florian Zabel

f.zabel@1mu.de

Wolfram Mauser

w.mauser@1mu.de

1 Department of Geography, Ludwig-Maximilians-Universität München, Luisenstrasse 37, 80333 Munich, Germany began in 1850 (IPCC 2014). However, there are significant regional differences in temperature and precipitation changes (IPCC 2013). Many studies have considered the impacts of future climate changes on food production at the global or very large scale (Iizumi et al. 2017; Lobell et al. 2008; Najafi et al. 2018; Parry et al. 2004).

However, there is a gap in regional impact studies, especially for Ethiopia, which is vulnerable to climate change, since it is not a food secure country (Alemu and Mengistu 2019; Cochrane 2018; Endalew et al. 2015; Mekonnen and Gerber 2017). Earlier studies on climate change impacts on crop production in Ethiopia were either at the national (Bryan et al. 2009; Kassie et al. 2014; Wubie 2015; Yalew et al. 2018) or larger scale such as the East African regional levels (Abera et al. 2018; Leal Filho et al. 2017; Niang et al. 2014). There are only a few studies at subnational levels within Ethiopia (Abera et al. 2018).

Ethiopia's economy is highly dominated by agriculture (Alemu and Mengistu 2019; Alemu et al. 2003; Yalew et al. 2018), contributing about $40 \%$ of the GDP (Shiferaw 2017). 
The World Bank's analysis predicts that climate change will lower Ethiopia's gross domestic product (GDP) growth by 0.5-2.5\% per annum (Gebreegziabher et al. 2016). In Ethiopia, effects of an enduring drought for continuous years from 1983 to 1985 reduced agricultural production in the county (Aragie 2013; Kassie et al. 2014). Food supply is one of society's key sensitivities to climate in Ethiopia (Porter et al. 2014).

The IPCC's fifth assessment report indicates that future climate change will lead to an increase in climate variability and in frequency and intensity of extreme events in Ethiopia (Niang et al. 2014). Over the past four decades, changing precipitation patterns (both dry and wet periods) have been observed in many parts of Ethiopia (Aragie 2013; Seleshi and Zanke 2004). Thereby, precipitation has shown a general decreasing trend since the 1990s (Leal Filho et al. 2017). This decrease already manifests in multiple effects on agricultural production in Ethiopia (Aragie 2013; Seleshi and Zanke 2004). In the last three decades, the Gambella region in the western part of Ethiopia was faced with frequent climatic variability and agro-ecological change (Gummadi et al. 2018). The changing rainfall pattern in combination with warming trends could make rainfed agriculture more risky and barrier food production in Ethiopia (Gebreegziabher et al. 2016) and in the region. For future conditions, a temperature increase of 2 to $2.5^{\circ} \mathrm{C}$ is supposed to have significant implications on agriculture in parts of Africa (Belloumi 2014) and Ethiopian (Leal Filho et al. 2017). In general, climate change induced increases in temperatures, and rainfall variation and the frequency and intensity of extreme weather events are adding pressures on Ethiopian agricultural production (Adhikari et al. 2015; Gbegbelegbe et al. 2014; Gebreegziabher et al. 2016). This creates challenges for the agricultural sector for possible future adaptation (FAO 2017).

For proper planning, it is required to investigate impacts of climate change on crop yields at regional scales. This is the first regional study that systematically investigates climate change impacts on agricultural production for Gambella in Ethiopia, exemplarily for maize. Over the last few decades, the maize yield in Ethiopia has shown an unprecedented transformation. Maize yields have doubled from about 1.6 $\mathrm{t} \mathrm{ha} \mathrm{a}^{-1}$ during the early $1990 \mathrm{~s}$ to $3.7 \mathrm{t} \mathrm{ha}^{-1}$ in recent years (Van Dijk et al. 2020). In 2016/2017, maize crop accounts for $57 \%$ of Gambella region's crop production by smallscale farmers and $56 \%$ of the region's harvested area (Degife et al. 2019). The following study comprises a representative selection of climate change impact scenarios to show the range of possible futures for different representative concentration pathways (RCPs). The approach is based on climate model results, which feed a processbased biophysical crop model that simulates crop yields under specific climate conditions.

\section{Data and methods}

\section{Study area}

Gambella is one of nine administrative regions in the southwestern part of Ethiopia. The region covers a total area of $25,521 \mathrm{~km}^{2}$ (Tadesse 2007). It shares borders with South Sudan and two other Ethiopian regions: Oromia to the north and east and the Southern Nations, Nationalities and Peoples' Regional State (SNNPRS) to the south (Fig. 1). Gambella region altitude progressively declines from east to west, ranging from $2200-1000 \mathrm{~m}$ a.s.l. in the east to $500-900 \mathrm{~m}$ in the center and 300-500 $\mathrm{m}$ in the west (Woube 1999). The mean annual temperature of the region varies from 17.3 to $28.3^{\circ} \mathrm{C}$ and the annual precipitation of the region varies from 800 to $1200 \mathrm{~mm}$ (Degife et al. 2019). The region is highly suitable for agriculture (Zabel et al. 2014).

\section{Climate data}

Dynamically downscaled general circulation models (GCM) projections have proven to be suitable tools for providing high-resolution climate drivers for regional and local assessments of climate change impacts and extremes (Shiferaw et al. 2018). We used climate data (near-surface air temperature, precipitation, surface downwelling longwave radiation, surface downwelling shortwave radiation, total cloud fraction, near-surface wind speed, sea level pressure, near-surface relative humidity) from the regional climate model Rossby Centre Regional Atmospheric Climate Model (RCA4) with large-scale forcing from five different GCMs (Table 1). They originated from the coupled model intercomparison project phase 5 (CMIP5). To capture the range of existing impact scenarios, we used three representative concentration pathways: from a very high baseline scenario (RCP 8.5), medium stabilization scenario (RCP 4.5), and a very low forcing level scenario (RCP 2.6). The authors do not consider medium stabilization scenarios (RCP 6.0) to prevent data replication (IPCC 2014; Van Vuuren et al. 2011).

RCA4 data was acquired over the African domain from the coordinated regional climate downscaling experiment (CORDEX) (Dosio and Panitz 2016) with horizontal grid spacing of $0.44^{\circ}(\approx 50 \mathrm{~km})$ and 3 -h temporal resolution. The applied data includes the historical period (1970-2005) and the RCPs representing climate change scenarios from 2020 until 2099. Both for the past and the future, each RCA4 run representing an RCP consists of a five-member ensemble from five different driving GCMs.

To use the climate data in the PROMET model (see the "PROMET model" section), we applied a statistical downscaling to 30 arc seconds and a temporal interpolation to $1 \mathrm{~h}$. Additionally, a bias correction was applied to temperature and precipitation after the downscaling and temporal interpolation 
Fig. 1 Gambella locational map: Federal Democratic Republic of Ethiopia (left) and Gambella regional state (right). Map uses UTM Zone $36 \mathrm{~N}$ projection
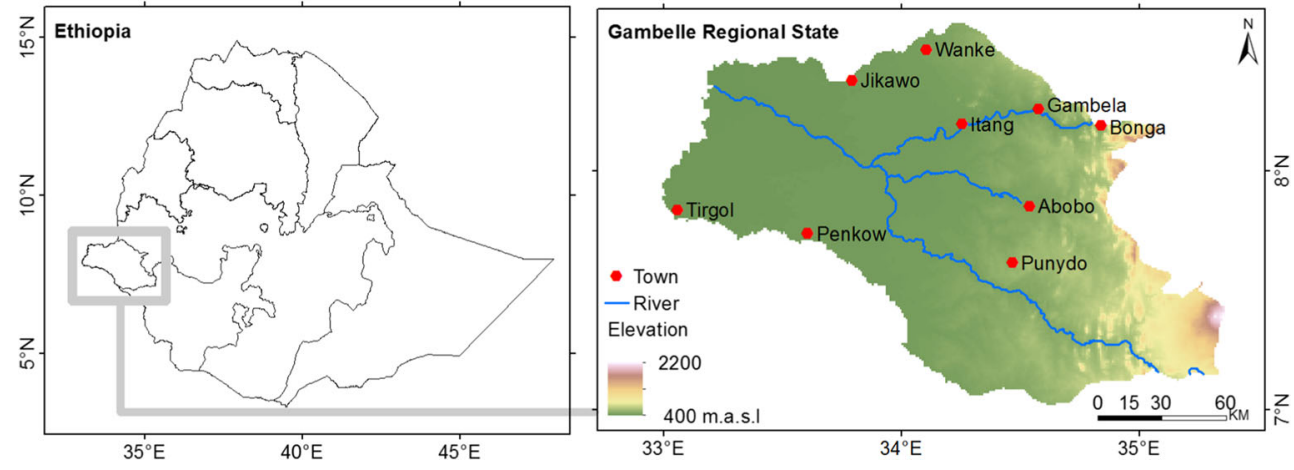

(Marke et al. 2014). For this, we used global monthly observation climatology from the WorldClim database v2 at 30 arc second resolution (Fick and Hijmans 2017). It is representative for the time period 1970-2000. The bias correction ensures that the average 1970-2000 monthly bias corrected and interpolated set of 5 climate model results of air temperature and precipitation at each of the 30 arc second grid cells that encompass Gambella region closely resemble the monthly values in the WorldClim dataset.

\section{PROMET model}

The PROMET model was applied to simulate crop growth of maize in the Gambella region (Delzeit et al. 2017; Hank et al. 2015; Mauser et al. 2015; Minoli et al. 2019; Zabel et al. 2019). The PROMET model is an agro-hydrological land surface process model, which contains mechanistic and biophysical parameters that operate at different spatial scales - from field scale to global scale. It was used because it is well parameterized and validated for maize in various regions (Müller et al. 2017; Franke et al. 2020). It uses first-order physical and physiological principles to determine net primary production and respiration based on approaches from Ball et al. (1987), Farquhar et al. (1980), and Xinyou and Van Laar (2005) combined with a phenology and a two-layer canopy architecture component. PROMET takes into account the dependency of net primary production and phenology on environmental conditions including meteorology, $\mathrm{CO}_{2}$ concentration for $\mathrm{C} 3$ and
C4 pathways, and water and temperature stress. The mass and energy balance of the canopy and underlying soil surface are iteratively closed for each simulation time step. The canopy and phenology component allocates assimilates into the different plant organs of the canopy depending on the phenological stage of development. The phenology model is described in detail in Minoli et al. (2019). Assimilates that are accumulated within the fruit fraction during the growing period determine the dry biomass available for yield formation. The simulation is performed on an hourly time step to account for non-linear reactions of crop growth to abiotic conditions like water and temperature stresses. Depending on the reaction of the considered crop to meteorological and soil-specific conditions, the crop either may die due to water, heat, or cold stress before being harvested or may not reach maturity. In both cases, this results in total yield loss.

In the context of this study, we simulate maize potential yields, assuming a perfect crop management. This means that crop is sowed at the appropriate date, perfectly supplied with nutrients at any time and pests and diseases are assumed to be controlled. These assumptions are chosen to isolate climate change impacts on yields without additional constraints. We simulated both rainfed and irrigated practices, in order to quantify the effect of irrigation for possible future adaptation. In the case of irrigation, we assume that no water stress occurs at any time.

Sowing dates are taken from available regional statistics for Gambella, stating that growing period starts in the middle of April. Sowing dates are kept constant and not shifted in this

Table 1 CMIP5 GCMs used in this study

\begin{tabular}{lll}
\hline Model & Description & Modeling center \\
\hline EC-EARTH & A European community Earth-System Model & EC-Earth consortium \\
HadGEM2-ES & Hadley Global Environmental & Met Office Hadley Centre (MOHC) \\
MIROC5 & Earth System Model 2 & International Centre for Earth Simulation \\
MPI-M-MPI-ESM-LR & Model for Interdisciplinary Research on Climate & Max Planck Institute for Meteorology (MPI-M) \\
NCC-NorESM1-M & MPI Earth System Model & Norwegian Climate Centre (NCC) \\
\hline
\end{tabular}


study in order to investigate the climate effect only. Maturity is simulated internally by PROMET according to the crop phenological progress.

We applied a settling time of 5 years (1970-1974) to all PROMET simulations for initializing soil moisture and other hydrological parameters, so that we use the 30 -year baseline period from 1975 to 2004.

\section{Decomposition analysis}

In order to separately quantify the different effects of increasing temperature, available soil water, and atmospheric $\mathrm{CO}_{2}$ concentration on the simulated potential yield, we applied a decomposition analysis for the 2070-2099 period. Therefore, we conducted all simulations for both rainfed and irrigated conditions. Additionally, we conducted a control run with fixed $\mathrm{CO}_{2}$ concentration at $360 \mathrm{ppm}$ until 2099 to isolate the beneficial effects of $\mathrm{CO}_{2}$.

First, to obtain the proportion of yield change due to temperature increase, we subtract 1975-2004 yields from yields in 2070-2099 from the irrigated fixed $\mathrm{CO}_{2}$ run, where $\mathrm{CO}_{2}$ and water have no effect. Second, we subtract the irrigated fixed $\mathrm{CO}_{2}$ 2070-2099 yields from the irrigated 2070-2099 yields with increased $\mathrm{CO}_{2}$ concentration to obtain the isolated benefit from $\mathrm{CO}_{2}$ fertilization. Third, we subtract the irrigated 2070-2099 yields from the rainfed yields to get the isolated effect of water stress on yields.

By comparing historical and future yields for the fixed irrigated $\mathrm{CO}_{2}$ yields, besides temperature, also other effects are cumulated, such as changes of wind speed and radiation, that impact on yields. Since PROMET considers the available soil water for the simulation of crop water stress, including a detailed description of relevant hydrologic processes in the soil-plant-atmosphere continuum, we refer to the water stress effect rather than precipitation in our analysis.

\section{Land-use scenario}

In this study, we assume that agricultural land in Gambella will expand into the not-yet-used legally available land for agricultural expansion. Therefore, all our results refer to all current cropland area in addition to the Top 50 expansion scenario according to Degife et al. (2019) and Zabel et al. (2019). The scenario assumes the use of today's cropland in addition to the best (in terms of highest potential yields) $50 \%$ expansion area. The used land is assumed to be constant over time in order to not affect the results.

\section{Results}

In average for 2070-2099, temperature increases by 1.6, 2.6, and 5.3 K under RCP 2.6, RCP 4.5, and RCP 8.5 scenarios for the Gambella region from April to September (Fig. 2), referring to the growing period of maize (Central Statistical Agency 2017). The model median of the average temperature in the region for the historical $1975-2004$ period is $26.5^{\circ} \mathrm{C}$.

Precipitation changes on average for 2070-2099 by -11.9 , -10.9 , and $-22.6 \%$ under RCP 2.6, RCP 4.5 , and RCP 8.5 scenarios for the Gambella region over the fixed statistical growing period of maize (Fig. 2). The model median of the absolute amount of precipitation in the region for the historical 1975-2004 period is $611 \mathrm{~mm}$. While the models agree quite well for temperature and precipitation change as can be seen by the model spread in Fig. 2, absolute precipitation values vary largely over historical periods (e.g., mean 1975-2004 values range between $888 \mathrm{~mm}$ for EC-EARTH and $530 \mathrm{~mm}$ for HadGEM2-ES). Overall, the tropical climate is characterized by hot temperatures and high precipitation.

The changing climate conditions have several impacts on maize yield that are described in the following, first showing impacts on rainfed maize, followed by showing impacts on irrigated maize. Subsequently, a decomposition analysis shows the different impacts of each, temperature, water availability, and $\mathrm{CO}_{2}$ on maize yield separately.

\section{Climate change impact on rainfed yields}

Figure 3 shows the temporal course of rainfed potential maize as median and min-max range of all five driving GCMs (Table 1) from 2020 to 2099 for RCP 2.6, RCP 4.5, and RCP 8.5 . Thereby, potential maize yield decreases by $1.1 \%$, 9.0\%, and 26.2\% under RCP 2.6, RCP 4.5, and RCP 8.5 respectively when applying a linear regression from 2020 to 2099. The model spread is decreasing with higher RCP. The range of models is between $-17.4 \%$ (MIROC5) and $17.2 \%$ (MPI-M-MPI-ESM-LR) for RCP 2.6, - 29.4\% (HadGEM2ES) and $-0.2 \%$ (MIROC5) for RCP 4.5, and between $37.6 \%$ (MPI-ESM) and $-20.5 \%$ (NCC-NorESM1-M) for RCP 8.5.

Slicing the time frame into 30-year climate normals (20102039, 2040-2069, and 2070-2099) and comparing each climate normal with the reference period (1975-2004), the right side of Fig. 3 shows the percentage change of potential rainfed maize yield under the three RCPs. Maize yield declines by $12.8 \%, 4.9 \%$, and $11.2 \%$ under RCP 2.6, RCP 4.5, and RCP 8.5 respectively for the time period $2010-2039$ and by $17.8 \%$, $14.9 \%$, and $22.1 \%$ under RCP 2.6, RCP 4.5, and RCP 8.5 respectively for the time period $2040-2069$ and by $14.7 \%$, $14.1 \%$, and $32.4 \%$ under RCP 2.6, RCP 4.5, and RCP 8.5 respectively for the time period 2070-2099. Thus, yields for RCP 2.6 and RCP 4.5 decrease until the middle of the century and do not further decrease until 2100 , while the decrease in RCP 8.5 continuously gets stronger. This effect is even stronger for irrigated conditions (compare the "Climate change impact on irrigated yields" section). Compared with Fig. 2, 
Fig. 2 Projected absolute change of near surface air temperature in kelvin (upper) and precipitation (lower) over the statistical growing period of maize (AprilSeptember) from 2020 to 2099 under RCP 2.6 (blue), RCP 4.5 (orange), and RCP 8.5 (red) compared to the reference period (1975-2004). The dark colored line shows the model median, while the light color surface shows the range of the five different driving GCMs between minimum and maximum ensemble member for each RCP. A 5a moving average is applied. The right side shows the boxplots of each of the 30-year averaged values over the range of all models, illustrating the median and the interquartile range ( 25 to 75 percentile), while the whiskers show the highest (max) and lowest (min) 30-year average value of all models
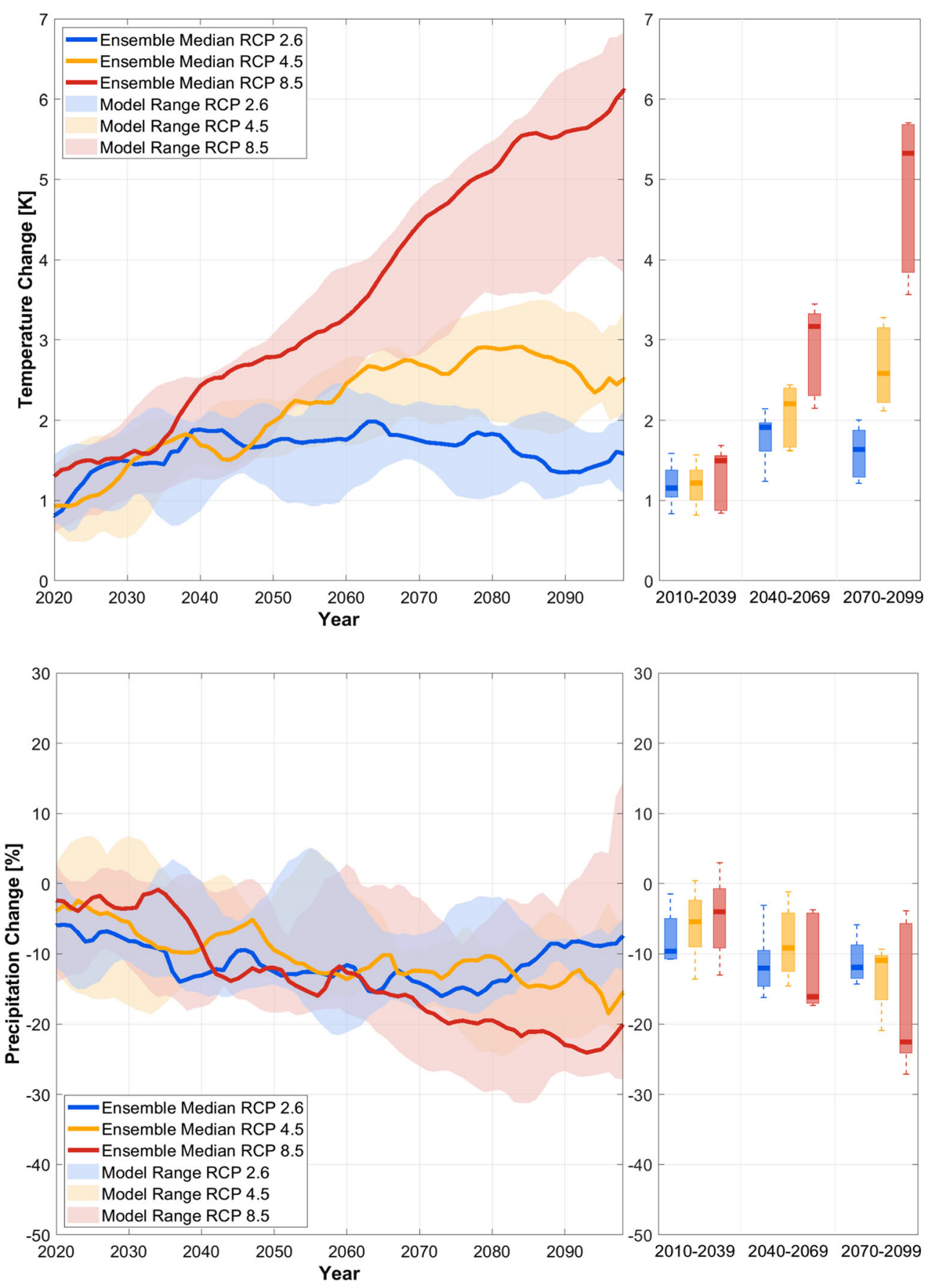

also temperature does not further increase after 2060 in RCPs 2.6 and 4.5 .

\section{Climate change impact on irrigated yields}

Figure 4 shows the temporal course of irrigated potential maize yield from 2020 to 2099 for RCP 2.6, RCP 4.5, and RCP 8.5 in comparison to the rainfed reference period (19752004). The potential irrigated maize yield decreases by $4.3 \%$, $23.0 \%$, and $44.5 \%$ under RCP 2.6, RCP 4.5, and RCP 8.5 respectively, but still is higher than the rainfed yield. The range of model results is between $-12.9 \%$ (MIROC5) and $7.2 \%$ (MPI-M-MPI-ESM-LR) for RCP 2.6, between $-37.1 \%$ (HadGEM2-ES) and $-17.8 \%$ (EC-EARTH) for RCP 4.5 , and between $-52.4 \%$ (HadGEM2-ES) and $-40.4 \%$ (NCC-NorESM1-M) for RCP 8.5.

Slicing the time frame into 30-year climate normals (20102039, 2040-2069, and 2070-2099) and comparing each climate normal with the reference period (1975-2004). Figure 4 shows maize irrigated yield changes by $+18.5 \%,+27.3 \%$, and $+18.5 \%$ under RCP 2.6 , RCP 4.5 , and RCP 8.5 respectively for the time period $2010-2039$ and by $8.7 \%, 4.9 \%$, and $-9.4 \%$ 
Fig. 3 Projected percentage change of rainfed maize potential yield from 2020 to 2099 under RCP 2.6 (blue), RCP 4.5

(orange), and RCP 8.5 (red) compared to the rainfed maize reference (1975-2004). The dark colored line shows the model median, while the light color surface shows the range of resulting yield from the five different driving GCMs between minimum and maximum ensemble member for each RCP. A 5a moving average is applied. The right side shows the boxplots of each of the 30year averaged yield over the range of all models, illustrating the median and the interquartile range ( 25 to 75 percentile), while the whiskers show the highest (max) and lowest $(\mathrm{min}) 30$-year average value of all models

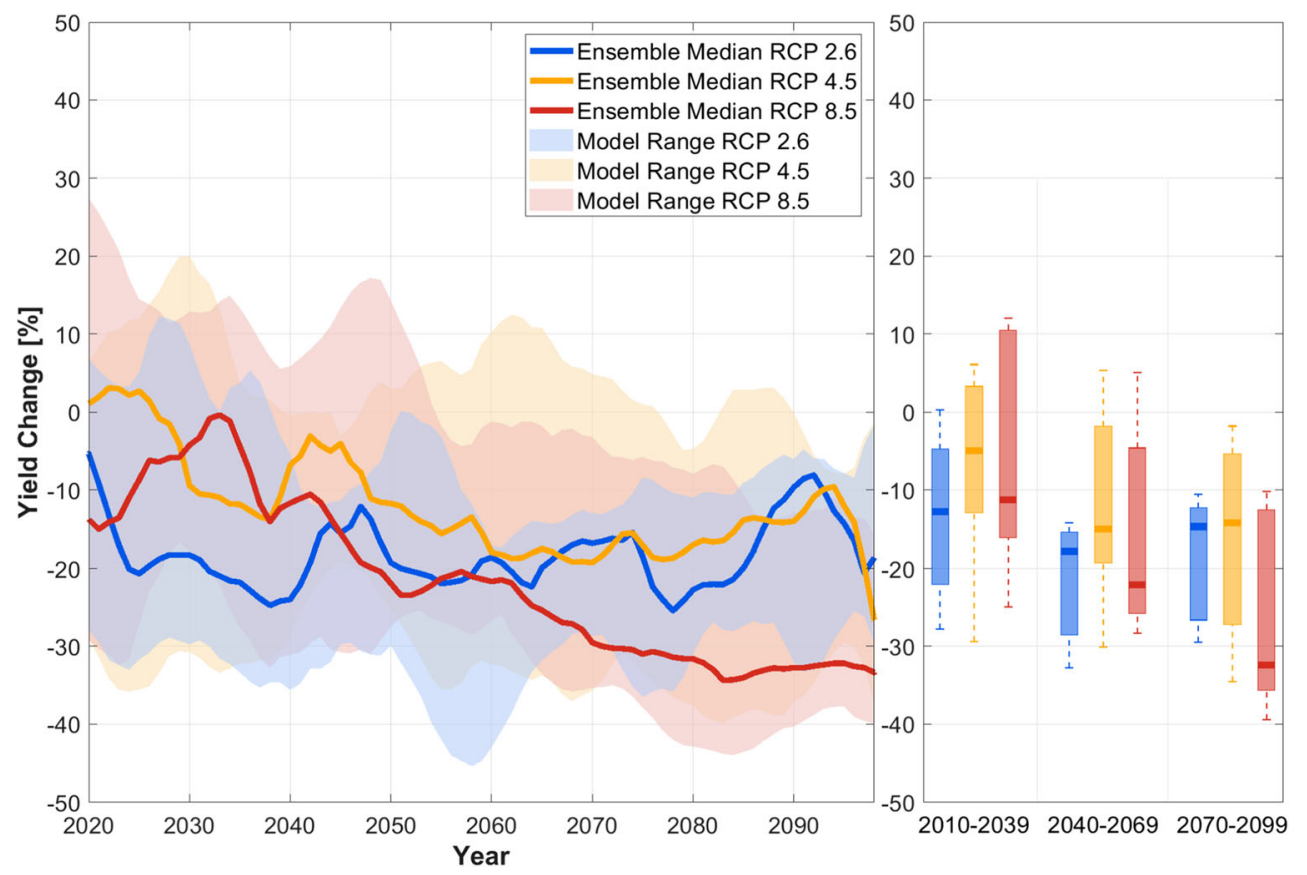

under RCP 2.6, RCP 4.5, and RCP 8.5 respectively for the time period 2040-2069 and by $17.7 \%, 1.4 \%$, and $-27.1 \%$ under RCP 2.6, RCP 4.5, and RCP 8.5 respectively for the time period 2070-2099.

Comparing Fig. 3 with Fig. 4, both relative to the rainfed reference, irrigated maize in percentage change decreases more than rainfed maize. However, irrigation still increases maize yield compared to rainfed until 2100, at least for RCP 2.6 and RCP 4.5, while for RCP 8.5 applying irrigation does not contribute to higher maize yield. Around the year 2050, irrigated maize yield will have the same magnitude than the reference rainfed yield for RCP 8.5.

\section{Decomposition analysis}

Figure 5 shows the contributions of temperature, water stress, and $\mathrm{CO}_{2}$ on maize yield changes for all RCPs until 20702099. Temperature contributes to total maize yield losses by up to $85 \%$ for RCP $8.5,67 \%$ for RCP 4.5 , and $52 \%$ for RCP 2.6. This demonstrates the strong dominance of temperature
Fig. 4 Projected percentage change of irrigated maize potential yield from 2020 to 2099 under RCP 2.6 (blue), RCP 4.5 (orange), and RCP 8.5 (red) compared to rainfed reference maize yield (1975-2004). The dark colored line shows the model median, while the light color surface shows the range of resulting yield from the five different driving GCMs between minimum and maximum ensemble member for each RCP. A 5a moving average is applied. The right side shows the boxplots of each of the 30year averaged yield over the range of all models, illustrating the median and the interquartile range ( 25 to 75 percentile), while the whiskers show the highest (max) and lowest (min) 30 year average value of all models

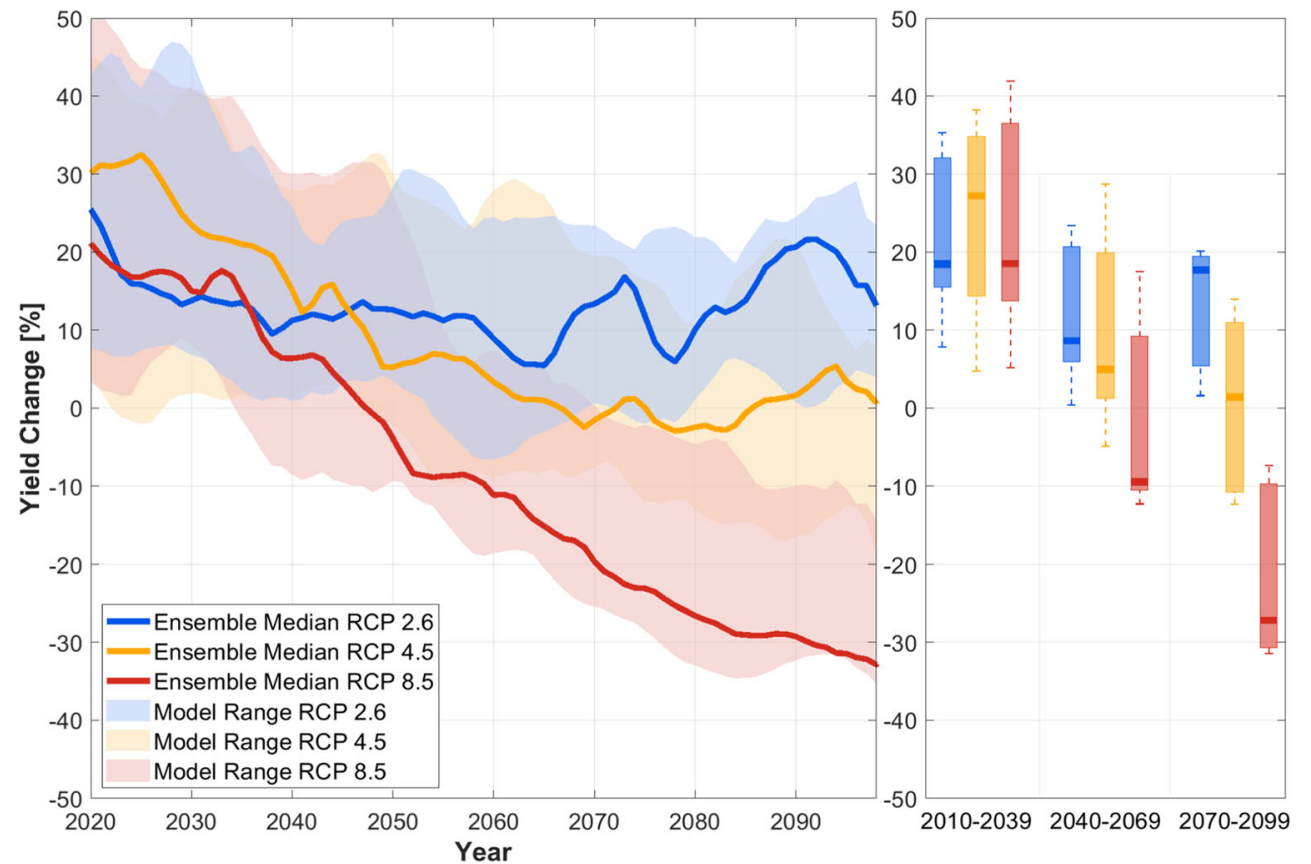




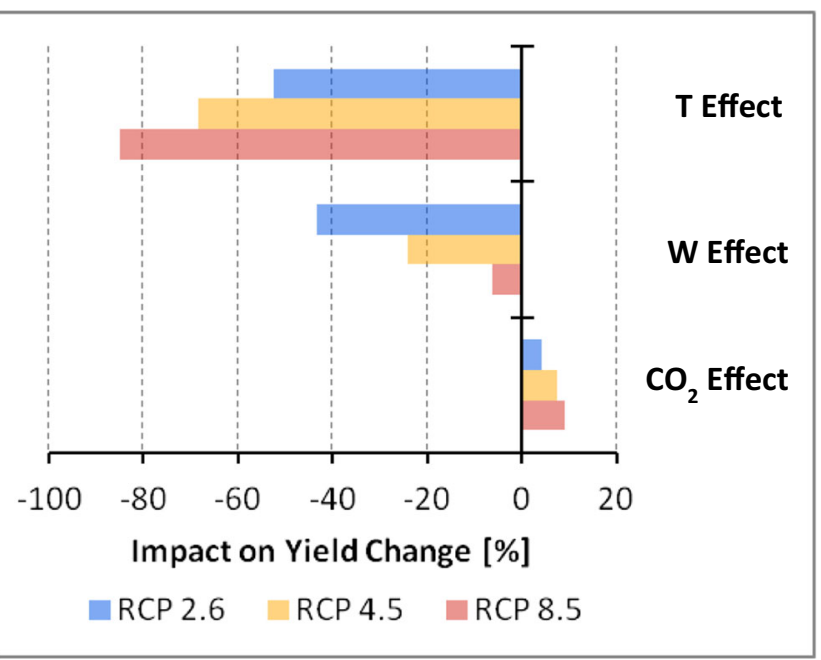

Fig. 5 Decomposition of temperature (T), water stress (W), $\mathrm{CO}_{2}$ impacts on yield. Each element shows the proportion on median maize potential yield change from the five different driving GCMs for the 30-year average period 2070-2099 under RCP 2.6 (blue), RCP 4.5 (orange), and RCP 8.5 (red)

stress for all RCPs in the Gambella region until the end of the century. It is the by far dominant effect responsible for yield reduction in the region, mainly in RCP 8.5. Temperature is becoming the limiting factor since crops reach its maximum temperature thresholds. On the other hand, the effect of water stress on maize yield is decreasing with higher RCPs. Water stress reduces maize yield by $43.4 \%$ for RCP $2.6,24.1 \%$ for RCP 4.5, and 6.2 for RCP 8.5. The positive $\mathrm{CO}_{2}$ effect on maize yield was expected to be low, since maize is $\mathrm{C} 4$ crops. The effect is highest for RCP 8.5 (increases maize yield by $8.9 \%$ ), because in this scenario also the highest $\mathrm{CO}_{2}$ concentrations occur.

In order to get deeper understanding on how temperature increase impacts on yields, we analyze the growing period length (number of days from sowing to maturity) in the Gambella region. Temperature affects crop yields not only by temperature limitations of photosynthesis but also by determining the phenological progress of crops. Thereby, crop varieties require different temperatures to reach maturity. Generally, higher temperature is associated with faster maturity that goes along with a reduced length of the growing period, which usually results in lower yields (Minoli et al. 2019). Besides temperature increase, water stress is another abiotic factor that can accelerate phenology during the reproductive stage and thus also leads to faster maturity.

Figure 6 shows a clear correlation $\left(R^{2} 0.81\right)$ between temperature increase and decreasing growing period length for irrigated maize under RCP 8.5, without the occurrence of water stress. The shortened growing period is strongly associated with yield reductions, shown by the strong correlation $\left(R^{2} 0.9\right)$ between growing period length and yield, which suggests that the impact of temperature increase on the growing period has an even larger effect on yields than temperature limitations on photosynthesis.

For the reference period (1975-2004), the growing period was 125 days for rainfed and 132 for irrigated. As expected, the growing period is shorter when considering water stress in rainfed case than for irrigated case. Figure 7 shows for all RCP scenarios the projected length of the growing period from 2020 to 2100 under rainfed and irrigated conditions. For all scenarios, the average growing period length becomes smaller, which means earlier mature harvest. While the growing period length is reduced by 5 days for RCP 2.6 both for irrigated and rainfed conditions between 2070 and 2099 in comparison with 2010-2039, it is reduced by 15 days for RCP 8.5 in case of irrigation and 11 days in case of rainfed. Compared to the reference, the growing period length decreases by 29 days in case of irrigation and by 23 days in case of rainfed until 2070-2099. Accordingly, the growing period is shortened more in the irrigated case than in the rainfed case, indicating that the effect of water stress on the growing period length is reduced. As visible in Fig. 7, the growing periods of irrigated and rainfed maize are getting more similar until the end of the century, since temperature increase alone (without
Fig. 6 Correlation between increasing near surface air temperature and the growing period length for irrigated maize (left) and between potential irrigated maize yield and the growing period length (right) for RCP 8.5 (2020-2099) in the Gambella region
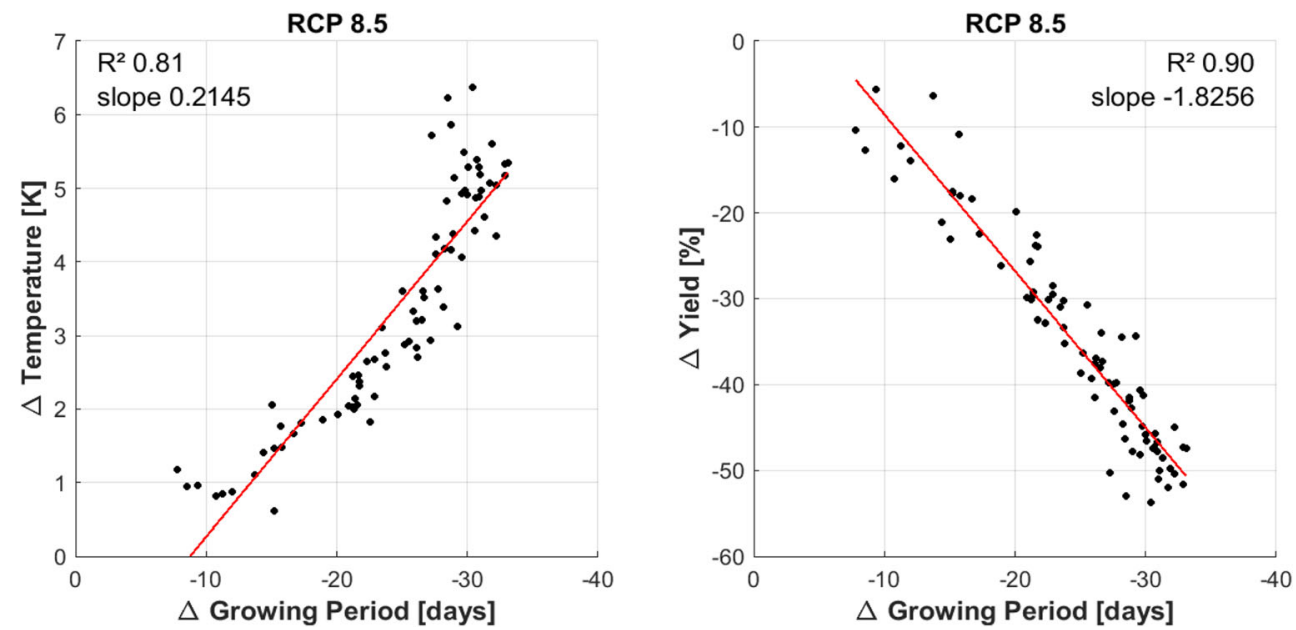
Fig. 7 Projected growing period length of rainfed (upper) and irrigated (lower) maize from 2020 to 2099 under RCP 2.6 (blue), RCP 4.5 (orange), and RCP 8.5 (red). The dark colored line shows the model median, while the light color surface shows the range of resulting maize yield from the five different driving GCMs between minimum and maximum ensemble member for each RCP. A 5a moving average is applied. The right side shows the boxplots of each of the 30-year averaged growing periods over the range of all models, illustrating the median and the interquartile range ( 25 to 75 percentile), while the whiskers show the highest (max) and lowest (min) 30-year average value of all models
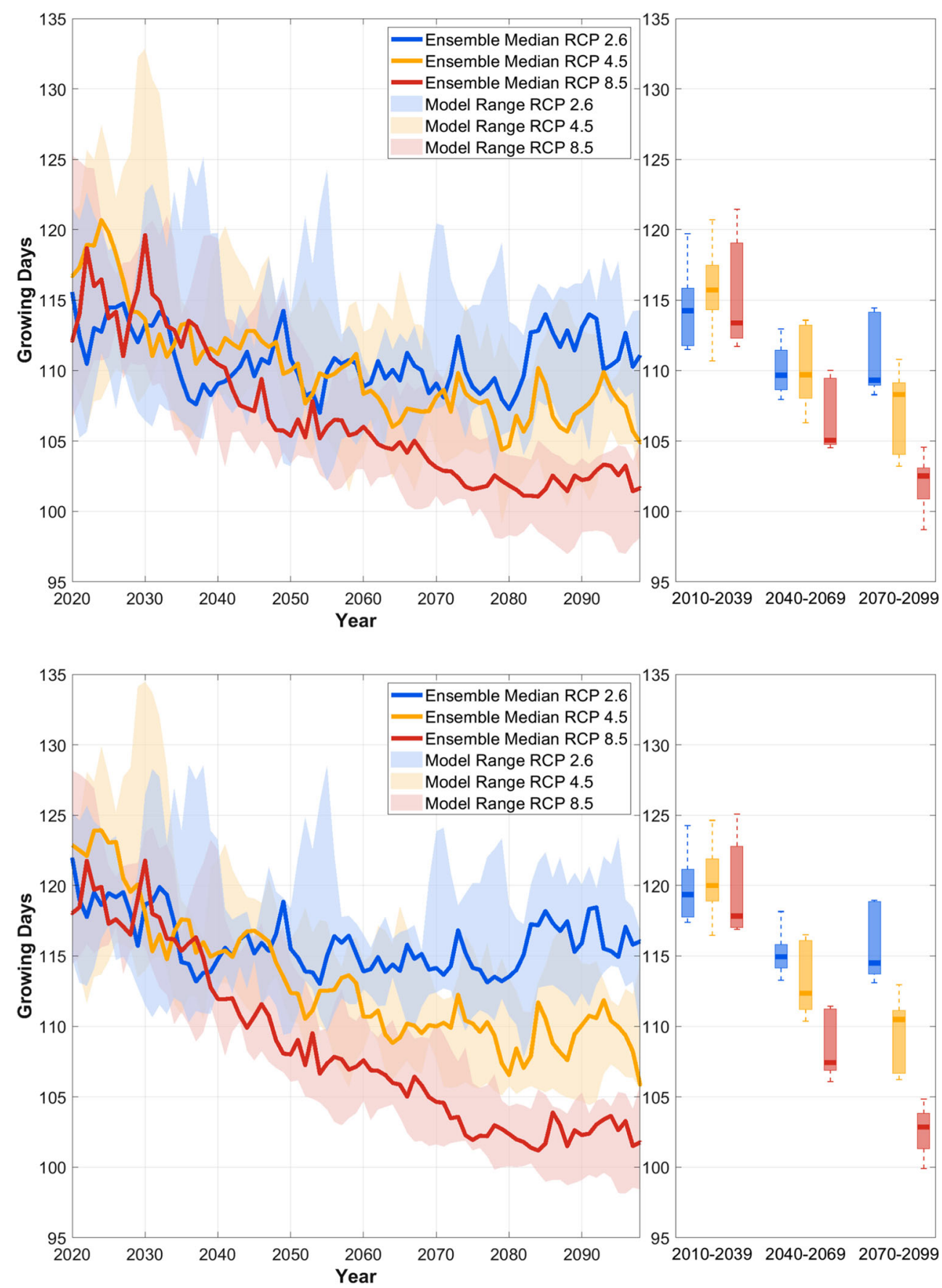

water stress) shortens the growing period in such a strong magnitude, that water stress occurs less frequently during the reproductive stage (Fig. 8).

\section{Discussion}

Agriculture is a sector that is closely linked to climate and that is thereby naturally prone to impacts of climate change (Bedeke et al. 2019; FAO 2016; Lobell et al. 2008). Therefore, the drivers of these changes must be understood to be able to propose more effective strategies for future food security (Alemu and Mengistu 2019; Najafi et al. 2018). We show in this paper the impact of climate change for different RCPs on potential maize yield in the Gambella region of Ethiopia, assuming the use of today's cropland in addition to the best $50 \%$ expansion area (Degife et al. 2019). Thereby, the RCPs describe ranges of possible future development and are selected to represent a low, medium, and strong climate change signal. The results demonstrate that maize potential yield is supposed to decrease under all selected RCPs, with highest yield reductions under RCP 8.5. 


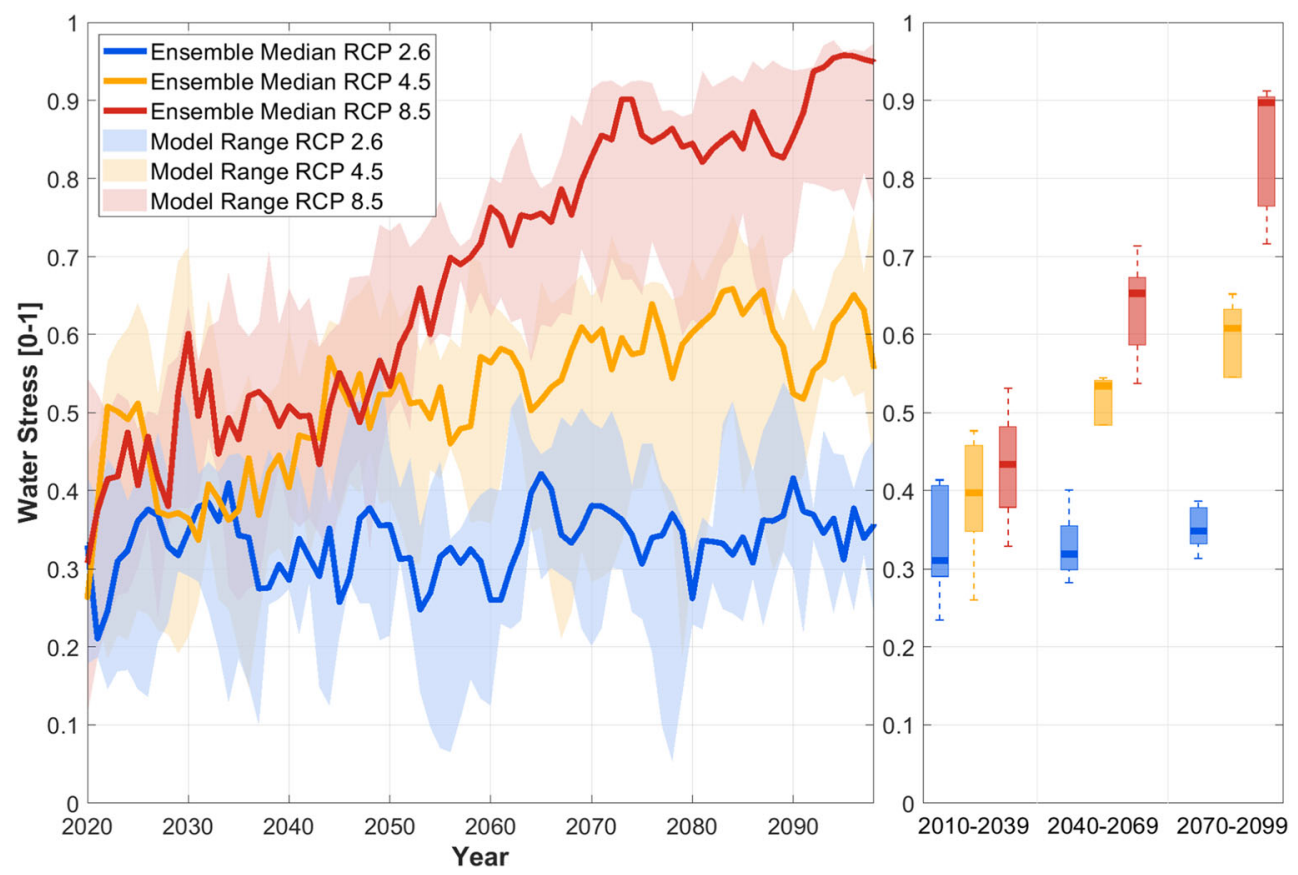

Fig. 8 Projected water stress for rainfed maize from 2020 to 2099 under RCP 2.6 (blue), RCP 4.5 (orange), and RCP 8.5 (red). Water stress is shown as a limiting factor between 0 and 1 , where 1 indicates no water stress, while 0 means a full limitation of available soil water. The dark colored line shows the model median, while the light color surface shows the range of resulting maize yield from the five different driving GCMs between minimum and maximum ensemble member for each RCP. A 5a moving average is applied. The right side shows the boxplots of each of the 30-year averaged growing periods over the range of all models, illustrating the median and the interquartile range ( 25 to 75 percentile), while the whiskers show the highest (max) and lowest (min) 30-year average value of all models
Although this RCP has the highest $\mathrm{CO}_{2}$ increase, the physiological effect of temperature increase is most dominant in this scenario, contributing to $85 \%$ of the reduction for rainfed maize yield. As we show, increasing temperature is the most contributing factor which reduces maize potential yield in the Gambella region with a prevailing tropical climate meaning already high temperature levels but also a high precipitation amounts. Thereby, increasing temperatures not only reduces the efficiency of photosynthesis but also results in a faster development of maize crop which leads to a shorter life cycle resulting in smaller plants, to a shorter reproductive duration (grain filling period), and finally to lower yields. These effects in summary result in less water demand of the crop and thus reduced water stress, although precipitation declines between 9.3 and $15.8 \%$. Given a temperature increase in Gambella by up to $6 \mathrm{~K}$ that results in maize yield decreases by approx. $30 \%$, our results support findings from other studies that show a reduction of yields by 5\% per degree warming (Challinor et al. 2014; Hatfield et al. 2011). Our results for $\mathrm{CO}_{2}$ responses are also in line with measurements from the Free Air $\mathrm{CO}_{2}$ Enrichment (FACE) experiments that show positive $\mathrm{CO}_{2}$ responses for maize by approximately $8 \%$ for a $550-\mathrm{ppm} \mathrm{CO}_{2}$ enrichment and irrigated conditions (Deryng et al. 2016) corresponding approximately to the atmospheric $\mathrm{CO}_{2}$ concentration under RCP 4.5, where our results show a positive $\mathrm{CO}_{2}$ response by $7.4 \%$.
Although temperature increase and shortening growing periods are supposed to affect increasing incidence of diseases, pests, and weeds outbreaks in Africa (Adhikari et al. 2015), it is important to note that the simulated yield decrease rates refer to potential yield, assuming perfect crop management. Despite the expected reductions of maize potential yield, intensification potentials still remain and are a major strategy for possible future production increase in the region, due to high yield gaps (Degife et al. 2019). However, our results also show that in the course of intensification, irrigation as a strategy for intensification will lose effectiveness, due to the increasing dominance of temperature stress.

Generally, our results refer to maize that provides a substantial portion of daily caloric intake in the Gambella region. Other crops may be affected differently by climate change impacts, depending on different crop physiologies and different crop management.

Another expected impact of future climate change is an increased occurrence of extreme weather events (Gezie 2019). While other studies showed that mean climate change may lead to asymmetrical responses in the frequency and intensity of severe weather events that can cause large-scale droughts, flooding, or severe reduction of crop yields in the study area (Milman and Arsano 2014; Regan et al. 2019; Wakuma Abaya et al. 2009), we did not consider single weather events in this study. As rainfall becomes more 
variable, farmers may no longer be able to rely on their knowledge of the seasonality of climatic variables. Shifting planting seasons and weather patterns will make it harder for farmers to maintain trust in planning and managing yield production (Akpodiogaga-a and Odjugo 2010; Lipper et al. 2014).

Adaptation as possible strategy to reduce climate change impacts is not considered in this study. An often discussed option is changing land-use patterns suggesting, e.g., relocating cropland to higher altitudes if available. However, relocation of cropland often is associated with negative impacts on ecosystems (Zabel et al. 2019) and higher altitudes are often not well suitable for agriculture (e.g., due to high slope). Shifting sowing dates and using adapted crop varieties or different cultivars are other possible measures for adaptation. Thereby, adapted crop varieties could prolong the shortened growing periods by increasing the heat units required to reach maturity. As shown by Minoli et al. (2019), the use of such adapted varieties potentially has a high impact on crop yields and can globally compensate warming up to $2 \mathrm{~K}$. By doing so, irrigation and available water from precipitation could again become an important factor for intensification and possible adaptation in the Gambella region, since it is likely that adapted varieties require more water when they grow longer. For further studies, the effect of adaptive growing seasons by assuming adapted varieties in addition to shifting sowing dates should be investigated both for rainfed and irrigated conditions.

The main challenge may be on how to incorporate available knowledge and technology for possible adaptation in the Gambella region in a process in which small-scale farmers are involved.

\section{Conclusion}

This study analyzes climate change impacts on the local scale and therefore is beneficial for local policy and decisionmakers and therefore allows for developing strategies for a sustainable agricultural development within the Gambella region under a range of possible future climate conditions. Maize is predominantly grown by smallholder farmers in the region, who mostly cultivate small parcels of land, which are often degraded. Climate change adds further challenges to the existing problems and undermines efforts that are being made to enhance food security in the region.

The strong heat response in the Gambella regions is mainly responsible for yield losses by more than $30 \%$ in case of rainfed and up to $50 \%$ in case of irrigation until the end of the century. Thereby, temperature increase is becoming the dominating effect over time and with higher RCP scenario, resulting in a decreasing role of water stress in context of yield reduction. Consequently, irrigation will lose effectiveness for increasing yields when temperature becomes the limiting factor. Providing new varieties from breeding could be a great benefit for the region. Thereby, our results suggest that adjusting the sowing date to minimize the impact of heat stress, as well as using late-maturing cultivars and new varieties are more effective and primarily required under future climate conditions for the Gambella region.

Funding Open Access funding enabled and organized by Projekt DEAL. A. Degife received financial support from the German Academic Exchange Service (DAAD).

Open Access This article is licensed under a Creative Commons Attribution 4.0 International License, which permits use, sharing, adaptation, distribution and reproduction in any medium or format, as long as you give appropriate credit to the original author(s) and the source, provide a link to the Creative Commons licence, and indicate if changes were made. The images or other third party material in this article are included in the article's Creative Commons licence, unless indicated otherwise in a credit line to the material. If material is not included in the article's Creative Commons licence and your intended use is not permitted by statutory regulation or exceeds the permitted use, you will need to obtain permission directly from the copyright holder. To view a copy of this licence, visit http://creativecommons.org/licenses/by/4.0/.

\section{References}

Abera K, Crespo O, Seid J, Mequanent F (2018) Simulating the impact of climate change on maize production in Ethiopia, East Africa. Environ Syst Res 7:4. https://doi.org/10.1186/s40068-018-0107-z

Adhikari U, Nejadhashemi AP, Woznicki SA (2015) Climate change and eastern Africa: a review of impact on major crops. Food Energy Secur 4:110-132. https://doi.org/10.1002/fes3.61

Akpodiogaga-a P, Odjugo O (2010) General overview of climate change impacts in Nigeria. J Hum Ecol 29:47-55. https://doi.org/10.1080/ 09709274.2010.11906248

Alemu T, Mengistu A (2019) Impacts of climate change on food security in Ethiopia: adaptation and mitigation options: a review. In: Castro P, Azul A, Leal FW, Azeiteiro U (eds) Climate Change-Resilient Agriculture and Agroforestry. Climate Change Management. Springer, Cham. https://doi.org/10.1007/978-3-319-75004-0_23

Alemu Z, Oosthuizen K, Van Schalkwyk H (2003) Contribution of agriculture in the Ethiopian economy: a time-varying parameter approach. Agrekon 42:29-48. https://doi.org/10.1080/03031853. 2003.9523608

Aragie EA (2013) Climate change, growth, and poverty in Ethiopia. Texas Univ at Austin. https://reliefweb.int/sites/reliefweb.int/files/ resources/working\%20paper\%20no\%203_final\%20.pdf. Accessed 4 Aug 2019

Ball JT, Woodrow I, Berry J (1987) A model predicting stomatal conductance and its contribution to the control of photosynthesis under different environmental conditions. Progress Photosynth Res 4:221224. https://doi.org/10.1007/978-94-017-0519-6_48

Barbier EB, Hochard JP (2018) The impacts of climate change on the poor in disadvantaged regions. Rev Environ Econ Policy 12:26-47. https://doi.org/10.1093/reep/rex023

Bedeke S, Vanhove W, Gezahegn M, Natarajan K, Van Damme P (2019) Adoption of climate change adaptation strategies by maizedependent smallholders in Ethiopia. NJAS-Wageningen J Life Sci 88:96-104. https://doi.org/10.1016/j.njas.2018.09.001 
Belloumi M (2014) Investigating the impact of climate change on agricultural production in Eastern and Southern African countries. AGRODEP Working Paper 0003. Washington, DC: International Food policy Research Ins. https:/www.ifpri.org/cdmref/ p15738coll2/id/128227/filename/128438.pdf

Bryan E, Deressa TT, Gbetibouo GA, Ringler C (2009) Adaptation to climate change in Ethiopia and South Africa: options and constraints. Environ Sci Pol 12:413-426. https://doi.org/10.1016/j. envsci.2008.11.002

Central Statistical Agency (2017) Agricultural sample survey area and production of major crops vol 1. Ministry of Agriculture Ethiopia, Addis Ababa, Ethiopia. https://www.statsethiopia.gov.et/wpcontent/uploads/2020/02/Area-and-Production-for-Major-CropsPrivate-Peasant-Holdings-Meher-Season-2017-18-2010-E.C..pdf

Challinor AJ, Watson J, Lobell DB, Howden SM, Smith DR et al (2014) A meta-analysis of crop yield under climate change and adaptation. Nat Clim Chang 4:287-291. https://doi.org/10.1038/nclimate2153

Cochrane L (2018) Food security in Ethiopia: review of Research, 20052016. Ethiop J Appl Sci Technol 9:1-10 https://journals.ju.edu.et/ index.php/ejast/article/view/703

Degife AW, Zabel F, Mauser W (2019) Land use scenarios and their effect on potential crop production: the case of Gambella Region, Ethiopia. Agriculture 9:105. https://doi.org/10.3390/ agriculture9050105

Delzeit R, Zabel F, Meyer C, Václavík T (2017) Addressing future tradeoffs between biodiversity and cropland expansion to improve food security. Reg Environ Chang 17:1429-1441. https://doi.org/10. 1007/s10113-016-0927-1

Deryng D, Elliott J, Folberth C, Müller C, Pugh TA et al (2016) Regional disparities in the beneficial effects of rising $\mathrm{CO}_{2}$ concentrations on crop water productivity. Nat Clim Chang 6:786-790. https://doi.org/ 10.1038 /nclimate2995

Diffenbaugh NS, Burke M (2019) Global warming has increased global economic inequality. Proc Natl Acad Sci 116:9808-9813. https:// doi.org/10.1073/pnas.1816020116

Dosio A, Panitz H-J (2016) Climate change projections for CORDEXAfrica with COSMO-CLM regional climate model and differences with the driving global climate models. Clim Dyn 46:1599-1625. https://doi.org/10.1007/s00382-015-2664-4

Endalew B, Muche M, Tadesse S (2015) Assessment of food security situation in Ethiopia: a review. Asian J Agric Res 9:55-68. https:// doi.org/10.3923/ajar.2015.55.68

FAO (2016) The state of food and agriculture. international cooperation 10:0. https:/www.uncclearn.org/wp-content/uploads/library/ai6030e.pdf

FAO (2017) The future of food and agriculture-Trends and challenges. FAO Rome. http://www.fao.org/3/a-i6881e.pdf

Farquhar GD, Caemmerer S, Berry JA (1980) A biochemical model of photosynthetic $\mathrm{CO}_{2}$ assimilation in leaves of $\mathrm{C} 3$ species. Planta 149: 78-90. https://doi.org/10.1007/BF00386231

Fick SE, Hijmans RJ (2017) WorldClim 2: new 1-km spatial resolution climate surfaces for global land areas. Int J Climatol 37:4302-4315. https://doi.org/10.1002/joc.5086

Franke JA, Müller C, Elliott J, Ruane AC, Jägermeyr J et al (2020) “The GGCMI Phase 2 experiment: global gridded crop model simulations under uniform changes in $\mathrm{CO}_{2}$, temperature, water, and nitrogen levels (protocol version 1.0)." Geosci. Model Dev 13(5):23152336. https://doi.org/10.5194/gmd-13-2315-2020

Gbegbelegbe S, Chung U, Shiferaw B, Msangi S, Tesfaye K (2014) Quantifying the impact of weather extremes on global food security: a spatial bio-economic approach. Weather Clim Extremes 4:96-108. https://doi.org/10.1016/j.wace.2014.05.005

Gebreegziabher Z, Stage J, Mekonnen A, Alemu A (2016) Climate change and the Ethiopian economy: a CGE analysis. Environment and Development Economics 21(2):205-225.
Gezie M (2019) Farmer's response to climate change and variability in Ethiopia: a review. Cogent Food Agric 5:1613770. https://doi.org/ 10.1080/23311932.2019.1613770

Gummadi S, Rao KPC, Seid J, Legesse G, Whitbread A et al (2018) Spatio-temporal variability and trends of precipitation and extreme rainfall events in Ethiopia in 1980-2010. Theor Appl Climatol 134: 1315-1328. https://doi.org/10.1007/s00704-017-2340-1

Hallegatte S, Fay M, Barbier EB (2018) Poverty and climate change: introduction. Environ Dev Econ 23:217-233. https://doi.org/10. 1017/S1355770X18000141

Hank TB, Bach H, Mauser W (2015) Using a remote sensing-supported hydro-agroecological model for field-scale simulation of heterogeneous crop growth and yield: application for wheat in central Europe. Remote Sens 7:3934-3965. https://doi.org/10.3390/ rs70403934

Hatfield JL, Boote KJ, Kimball BA, Ziska LH, Izaurralde RC et al (2011) Climate impacts on agriculture: implications for crop production. Agron J 103:351-370. https://doi.org/10.2134/agronj2010.0303

Iizumi T, Furuya J, Shen Z, Kim W, Okada M et al (2017) Responses of crop yield growth to global temperature and socioeconomic changes. Sci Rep 7:7800. https://doi.org/10.1038/s41598-017-08214-4

IPCC (2013) Climate Change 2013: The physical science basis. In: Stocker TF, Qin D, Plattner GK, Tignor M, Allen SK, Boschung J, Nauels A, Xia Y, Bex V, Midgley PM (eds) Contribution of working group I to the fifth assessment report of the Intergovernmental panel on climate change. Cambridge University Press, Cambridge, UK and New York, pp 1535.

IPCC (2014) Climate change 2014: synthesis report. In: Core Writing Team, Pachauri RK, Meyer LA (eds) Contribution of working groups I, II, III to the fifth asessment report of the Intergovermental panel on climate change. IPCC, Switzerland, $p$ 151.

Kassie B, Rötter R, Hengsdijk H, Asseng S, Van Ittersum M et al (2014) Climate variability and change in the central rift valley of Ethiopia: challenges for rainfed crop production. J Agric Sci 152:58-74. https://doi.org/10.1017/S0021859612000986

Leal Filho W, Simane B, Kalangu J, Wuta M, Munishi P et al (2017) Climate change adaptation in Africa. Springer International Publishing. https://link.springer.com/book/10.1007\%2F978-3-31949520-0\#about

Lipper L, Thornton P, Campbell BM, Baedeker T, Braimoh A et al (2014) Climate-smart agriculture for food security. Nat Clim Chang 4: 1068-1072. https://doi.org/10.1038/nclimate2437

Lobell DB, Burke MB, Tebaldi C, Mastrandrea MD, Falcon WP et al (2008) Prioritizing climate change adaptation needs for food security in 2030. Science 319:607-610. https://doi.org/10.1126/science. 1152339

Marke T, Mauser W, Pfeiffer A, Zängl G, Jacob D et al (2014) Application of a hydrometeorological model chain to investigate the effect of global boundaries and downscaling on simulated river discharge. Environ Earth Sci 71:4849-4868. https://doi.org/10. 1007/s12665-013-2876-Z

Mauser W, Klepper G, Zabel F, Delzeit R, Hank T et al (2015) Global biomass production potentials exceed expected future demand without the need for cropland expansion. Nat Commun:6. https://doi.org/ 10.1038 /ncomms9946

Mekonnen DA, Gerber N (2017) Aspirations and food security in rural Ethiopia. Food Security 9:371-385. https://doi.org/10.1007/s12571017-0654-6

Milman A, Arsano Y (2014) Climate adaptation and development: contradictions for human security in Gambella, Ethiopia. Glob Environ Chang 29:349-359. https://doi.org/10.1016/j.gloenvcha.2013.11. 017

Minoli S, Müller C, Elliott J, Ruane AC, Jägermeyr J et al (2019) Global response patterns of major rainfed crops to adaptation by 
maintaining current growing periods and irrigation. Earth's Future. https://doi.org/10.1029/2018ef001130

Müller C, Elliott J, Chryssanthacopoulos J, Arneth A, Balkovic J et al (2017) Global gridded crop model evaluation: benchmarking, skills, deficiencies and implications. Geosci Model Dev 10(4):1403-1422. https://doi.org/10.5194/gmd-10-1403-2017

Najafi E, Devineni N, Khanbilvardi RM, Kogan F (2018) Understanding the changes in global crop yields through changes in climate and technology. Earth's Future 6:410-427. https://doi.org/10.1002/ 2017EF000690

Niang I, Ruppel OC, Abdrabo MA, Essel A, Lennard C et al (2014) Africa climate change 2014: impacts, adaptation, and vulnerability. In: Barros VR, Field CB, Dokken DJ, Mastrandrea MD, Mach KJ, Bilir TE, Catterjee M, Ebi KL, Estrada YO, Genova RC, Girma B, Kissel ES, Levy AN, MacCracken S, Mastrandrea PR, White LL (eds) Part B: regional aspects. Contribution of working group II to the fifth assessment report of the intergovernmental panel on climate change. Cambridge University Press, Cambridge, UK, and New York, p 1199-1265.

Parry ML, Rosenzweig C, Iglesias A, Livermore M, Fischer G (2004) Effects of climate change on global food production under SRES emissions and socio-economic scenarios. Glob Environ Chang 14: 53-67 https://doi.org/10.1016/j.gloenvcha.2003.10.008

Porter JR, Xie L, Challinor AJ, Cochrane K, Howden SM et al (2014) Food security and food production systems. Climate change 2014: impacts, adaptation, and vulnerability. In: Field CB, Barros VR, Dokken DJ, Mastrandrea MD, Mach KJ, Bilir TE, Catterjee M, Ebi KL, Estrada YO, Genova RC, Girma B, Kissel ES, Levy AN, MacCracken S, Mastrandrea PR, White LL (eds) Part A: Global and Sectoral Aspects. Contribution of working group II to the fifth assessment report of the intergovernmental panel on climate change. Cambridge University Press, Cambridge, UK and New York, $p$ 485-533. https://www.ipcc.ch/site/assets/uploads/2018/02/ WGIIAR5-Chap7_FINAL.pdf

Regan PM, Kim H, Maiden E (2019) Climate change, adaptation, and agricultural output. Reg Environ Chang 19:113-123. https://doi.org/ 10.1007/s10113-018-1364-0

Seleshi Y, Zanke U (2004) Recent changes in rainfall and rainy days in Ethiopia. Int J Climatol 24:973-983. https://doi.org/10.1002/joc. 1052

Shiferaw A (2017) Productive capacity and economic growth in Ethiopia. United Nations, Department of Economics and Social Affairs. https://www.un.org/development/desa/dpad/wp-content/uploads/ sites/45/publication/CDP_BP34_April_2017.pdf
Shiferaw A, Tadesse T, Rowe C, Oglesby R (2018) Precipitation extremes in dynamically downscaled climate scenarios over the greater horn of Africa. Atmosphere 9:112. https://doi.org/10.3390/ atmos 9030112

Tadesse M (2007) Gambella The impact of local conflict on regional security. Institute for Security Studies (ISS), Addis Ababa, Ethiopia. https://css.ethz.ch/en/services/digital-library/publications/ publication.html/123907

Van Dijk M, Morley T, van Loon M, Reidsma P, Tesfaye K et al (2020) Reducing the maize yield gap in Ethiopia: decomposition and policy simulation. Agric Syst 83:1-11. https://doi.org/10.1016/j.agsy. 2020.102828

Van Vuuren DP, Edmonds J, Kainuma M, Riahi K, Thomson A et al (2011) The representative concentration pathways: an overview. Clim Chang 109:5. https://doi.org/10.1007/s10584-011-0148-z

Wakuma Abaya S, Mandere N, Ewald G (2009) Floods and health in Gambella region, Ethiopia: a qualitative assessment of the strengths and weaknesses of coping mechanisms. Glob Health Action 2:2019. https://doi.org/10.3402/gha.v2i0.2019

Woube M (1999) Flooding and sustainable land-water management in the lower Baro-Akobo river basin, Ethiopia. Appl Geogr 19:235251. https://doi.org/10.1016/S0143-6228(99)00004-1

Wubie AA (2015) Review on the impact of climate change on crop production in Ethiopia. J Biol Agric Healthcare 5:103-111 https:// www.iiste.org/Journals/index.php/JBAH/article/view/23959/24530

Xinyou Y, Van Laar H (2005) Crop systems dynamics: an ecophysiological simulation model for genotype-by-environment interactions. Wageningen Academic Pub. https://doi.org/10.1016/j.agsy.2008. 03.003

Yalew AW, Hirte G, Lotze-Campen H, Tscharaktschiew S (2018) Climate change, agriculture, and economic development in Ethiopia. Sustainability 10:3464. https://doi.org/10.3390/ su10103464

Zabel F, Putzenlechner B, Mauser W (2014) Global agricultural land resources-a high resolution suitability evaluation and its perspectives until 2100 under climate change conditions. PLoS One 9: e107522. https://doi.org/10.1371/journal.pone.0107522

Zabel F, Delzeit R, Schneider JM, Seppelt R, Mauser W et al (2019) Global impacts of future cropland expansion and intensification on agricultural markets and biodiversity. Nat Commun 10:2844. https://doi.org/10.1038/s41467-019-10775-z

Publisher's note Springer Nature remains neutral with regard to jurisdictional claims in published maps and institutional affiliations. 